\title{
ANALISIS SIKAP SOSIAL SISWA SEKOLAH DASAR PADA PEMBELAJARAN TEMATIK DENGAN MODEL INKUIRI TERBIMBING
}

\author{
Sudarsri Lestari ${ }^{1}$, Erisy Syawiril Ammah ${ }^{2}$, Eka Ramiati ${ }^{3}$ \\ 1,3Institut Agama Islam (IAI) Ibrahimy Genteng Banyuwangi, Indonesia \\ 2Institut Agama Islam Negeri (IAIN) Jember, Indonesia \\ e-mail: ${ }^{1}$ sudarsrilestari.iaii@gmail.com, 22syawirilammmah@gmail.com, \\ 3numateraeka@gmail.com
}

\begin{abstract}
Thematic learning can be strengthened by research based learning such as inquiry, so that collaboration can contribute to one another in building active and studentcentered learning, and can have a positive influence on students' social attitudes. Based on the description, a study was conducted with the aim of: (1) knowing the implementation of thematic learning with the guided inquiry model; and (2) knowing students' social attitudes on thematic learning with the guided inquiry model. This study uses a qualitative approach, with field research designs. Data collection techniques using interviews, observation, and field notes. The results showed that: (1) teachers and students could carry out the thematic learning stages with guided inquiry models in learning 1 to 6 very effectively; and (2) students' attitudes towards thematic learning with guided inquiry models experience positive development. In learning 1, students' social attitudes are still dominant. While in learning 2, social attitude began to develop. Continued in learning 3 and 4, most of the social students begin to develop and culture, and in learning 5 and 6 the majority of students have a social attitude.
\end{abstract}

Keywords: Thematic learning, guided inquiry model, and students social attitude

\begin{tabular}{|c|c|c|}
\hline Accepted: & Reviewed: & Publised: \\
April 12 2020 & Juni 02 2020 & September 12020 \\
\hline
\end{tabular}

\section{A. Pendahuluan}

Pembelajaran tematik integratif dari kelas 1 sampai kelas 6 digunakan pada Kurikulum 2013 untuk SD/MI. Hal itu berlandaskan pada kecenderungan belajar anak usia sekolah dasar yang mempunyai tiga ciri penting, yaitu konkret, integratif, dan hierarki. Tidak dapat dipungkiri bahwa pembelajaran tematik merupakan salah satu model dari pembelajaran terpadu dimana pembelajaran dilaksanakan dengan melibatkan kolaborasi mata pelajaran yang terkait dalam satu tema untuk memberikan pengalaman yang bermakna kepada siswa (Rusman, 2012).

Pembelajaran tematik terpadu yang diterapkan di SD dalam kurikulum 2013 berlandaskan pada Permendikbud Nomor 22 Tahun 2016 tentang Standar Proses

This work is licensed under Creative Commons Attribution Non Commercial 4.0 International License Available online on: http://ejournal.iaiibrahimy.ac.id/index.php/tarbiyatuna 
Pendidikan Dasar dan Menengah. Terdapat pendekatan yang biasanya digunakan untuk mengintegrasikan kompetensi dasar dari berbagai mata pelajaran yaitu; inter-disipliner, intra-disipliner, multi-disipliner dan trans-disipliner. Tema digunakan untuk mengaitkan kompetensi dasar dari berbagai mata pelajaran. Selain itu, pembelajaran tematik juga mengangkat isu permasalahan yang ada di lingkungan sekitar siswa.

Agar seluruh rangkaian pembelajaran tematik dapat terlaksana secara maksimal, perlu adanya berbagai variasi kegiatan dengan mengimplementasikan berbagai model pembelajaran. Keterlibatan peserta didik pada pembelajaran tematik lebih ditekankan dalam proses pembelajaran atau mengarahkan secara aktif dalam proses pembelajaran. Melalui pembelajaran tematik peserta didik dapat memperoleh pengalaman langsung untuk menemukan sendiri berbagai pengetahuan yang dipelajari secara holistik, autentik, aktif dan bermakna.

Dalam proses pembelajaran sendiri tidak luput dari penggunaan metode, model dan strategi yang harus dilakukan oleh pendidik sebagai cara yang harus digunakan untuk menambah efektifitas pembelajaran, baik pembelajaran umum maupun pembelajaran Pendidikan Agama Islam (PAI)(Dewi, Muttaqin, and Muftiyah 2019). Salah satu model pembelajaran yang dapat digunakan untuk mendukung pembelajaran tematik adalah model inkuiri terbimbing. Menurut Eggen dan Kauchak (2012); Rusman (2012) penggunaan inkuiri terbimbing dapat meningkatkan motivasi siswa dalam belajar, karena dalam penggunaan inkuiri terbimbing mengembangkan kegiatan dan pengalaman yang membangkitkan tantangan dan rasa ingin tahu pada diri siswa. Jika dilihat dari kepuasan emosional, hasil menemukan sendiri memiliki nilai kepuasan lebih tinggi jika dibandingkan dengan hasil pemberian.

Tujuan utama inkuiri adalah membantu siswa mengembangkan keterampilan intelektual, berpikir kritis, dan mampu memecahkan masalah secara alamiah (Dimyati dan Mudjiono, 2006). Menurut Mbulu (2001), ada tiga jenis model inkuiri, yakni (1) inkuiri terbimbing; (2) inkuiri bebas; dan (3) inkuiri bebas yang dimodifikasikan.

Pada kegiatan pembelajaran inkuiri terbimbing, kegiatan pemilihan masalah ditentukan oleh guru, tetapi penemuan konsep dilakukan oleh siswa melalui pertanyaan yang mengarah pada penemuan konsep yang diberikan oleh guru. Pada model inkuiri terbimbing, guru lebih banyak mengarahkan dan memberikan petunjuk, baik melalui prosedur yang lengkap maupun pertanyaan-pertanyaan pengarahan pada proses inkuiri. Dalam menyelesaikan persoalan, siswa harus menyesuaikan dengan prosedur yang dibuat oleh guru, sehingga siswa kurang bebas mengembangkan gagasan dan idenya. Peran guru pada proses inkuiri, 
misalnya dapat memberikan pertanyaan yang menggugah di sela-sela proses inkuiri, sehingga simpulan lebih cepat diperoleh.

Menurut Mbulu (2001), kelebihan model inkuiri terbimbing adalah: (a) siswa dapat memahami suatu konsep, karena siswa mengalami sendiri proses untuk mendapatkan konsep tersebut; (b) siswa didorong untuk berpikir dan bekerja atas inisiatif sendiri, sehingga lebih merangsang kemauan siswa; (c) melatih siswa memecahkan masalah secara mandiri, namun terbimbing; (d) siswa memiliki keterampilan berpikir kritis karena dituntut untuk selalu menganalisis dan menangani informasi yang diperoleh; (e) memberikan kepada siswa pengalaman belajar yang nyata dan aktif, karena siswa dilatih memecahkan masalah, membuat keputusan, dan memperoleh keterampilan. Menurut Kuhlthau et al (2012), terdapat delapan tahapan proses pembelajaran dengan model inkuiri terbimbing, yaitu open, immerse, explore, identify, gather, create, share, dan evaluate.

Menurut Fitriyani (2019), model inkuiri terbimbing sangat tepat untuk diterapkan pada pembelajaran tematik, khususnya di kelas tinggi. Melalui inkuiri terbimbing, siswa menjadi lebih terampil dalam menemukan masalah dan melatih siswa menghadapi masalah dengan bantuan guru. Lestari (2015), juga menyatakan bahwa model inkuiri terbimbing dapat berpengaruh terhadap sikap ilmiah siswa, keterampilan proses sains, dan penguasaan konsep pada siswa sekolah dasar. Berdasarkan hasil tersebut dapat disimpulkan bahwa model inkuiri terbimbing dapat dijadikan sebagai alternatif pemilihan model pembelajaran di sekolah dasar.

Kurikulum 2013 menekankan pada pengembangan kompetensi sikap, pengetahuan, dan keterampilan siswa secara seimbang (Permendikbud Nomor 23 Tahun 2016). Kompetensi sikap, pengetahuan, dan keterampilan pertama kali dtemukan oleh Bloom pada tahun 1965 yang kemudian dijadikan sebagai dasar dalam pengembangan kurikulum di Indonesia sejak tahun 1973 (Widyastono, 2014). Namun pada implementasi sebelum diberlakukannya kurikulum 2013, guru tidak mengembangkan sikap dan keterampilan secara eksplisit, melainkan pengetahuan menjadi prioritas dalam pengembangan kompetensi.

Penilaian sikap pada kurikulum 2013 dibedakan menjadi sikap spiritual dan sikap sosial. Sikap berawal dari perasaan yang berkaitan dengan kecenderungan seseorang dalam memberikan respon terhadap sesuatu atau objek. Penilaian kompetensi sikap sosial pada pembelajaran dapat dimaknai sebagai rangkaian kegiatan pembelajaran yang didesain untuk mengukur sikap siswa sebagai hasil dari program belajar. Sikap merupakan bagian dari hasil belajar afektif. Hasil belajar afektif adalah hasil belajar yang berupa aspek-aspek nonintelektual seperti sikap, minat, nilai, dan moral (Harsiati, 2011). Sikap selalu berkenaan dengan suatu obyek, dan sikap terhadap obyek ini disertai dengan perasaan positif atau 
negatif terhadap obyek yang dipandangnya. Sikap merupakan kemampuan internal yang berperan sekali dalam mengambilan tindakan (Winkel, 1995).

Penilaian sikap sosial pada siswa kelas IV SDN 3 Sarimulyo berlangsung dengan baik. Berdasarkan hasil observasi 29-31 Juli 2019, guru biasanya menilai sikap sosial siswa pada saat kegiatan pembelajaran berlangsung. Namun, membentuk sikap positif pada siswa bukanlah hal yang mudah. Sikap tidak dapat terbentuk secara instan. Berdasarkan hasil wawancara pada tanggal 31 Juli 2019, guru menyatakan telah mencoba melakukan berbagai inovasi dalam pembelajaran guna membudayakan sikap positif pada diri siswa. Salah satu inovasi yang dilakukan adalah dengan mengkolaborasikan pembelajaran tematik dengan model pembelajaran inkuiri terbimbing.

Pembelajaran tematik dapat diperkuat dengan pembelajaran berbasis penyikapan/penelitian seperti inkuiri sehingga melalui kolaborasi tersebut keduanya dapat saling berkontribusi dalam membangun pembelajaran yang aktif dan berpusat pada siswa, serta dapat memberikan pengaruh positif terhadap sikap sosial siswa. Berdasarkan uraian di atas, maka dilakukan penelitian dengan tujuan untuk mengetahui pelaksanaan pembelajaran tematik dengan model inkuiri terbimbing, dan sikap sosial siswa pada pembelajaran tematik dengan model inkuiri terbimbing.

\section{B. Metode Penelitian}

Penelitian ini menggunakan pendekatan kualitatif dengan jenis penelitian lapangan (field reasearch), dimana peneliti berangkat untuk mengadakan pengamatan tentang suatu fenomenon dalam suatu keadaan alamiah, dalam hal ini erat kaitannya dengan pengamatan dan peranserta (Moleong, 2012). Penelitian dilakukan terhadap 33 siswa kelas IV SDN 3 Sarimulyo Banyuwangi pada semester ganjil tahun pelajaran 2019/2020. Pada penelitian ini, peneliti bertindak sebagai key instrument atau instrumen kunci dalam penelitian. Pengumpulan data dilakukan dengan menggunakan teknik observasi, wawancara, dan catatan lapangan.

Teknik observasi digunakan untuk memperoleh data tentang sikap sosial siswa dan keterlaksanaan pembelajaran tematik dengan model inkuiri terbimbing. Teknik wawancara dilakukan terhadap guru dan siswa kelas IV. Pedoman wawancara digunakan untuk mempermudah berlangsungnya kegiatan wawancara. Pedoman wawancara yang dibuat berisi tentang garis besar pertanyaan yang akan diajukan. Wawancara dilakukan sebelum dan sesudah pelaksanaan pembelajaran tematik dengan model inkuiri terbimbing. Wawancara sebelum pelaksanaan pembelajaran dimaksudkan untuk memperoleh data awal 
tentang pembelajaran dan kesulitan yang dihadapi guru. Wawancara setelah pelaksanaan pembelajaran dimaksudkan untuk mengetahui respon guru dan siswa terhadap proses pembelajaran tematik dengan model inkuiri terbimbing. Catatan lapangan dibuat oleh peneliti untuk mendokumentasikan aktivitas atau kegiatan selama proses aktivitas selama proses penelitian berlangsung. Catatan lapangan tersebut dibuat dengan cara mencatat data-data faktual pada proses pembelajaran.

Teknik analisis data dilakukan dengan menggunakan model alir (Miles dan Hubberman, 1992: 18) yang meliputi, (1) reduksi data, (2) penyajian data, (3) penarikan kesimpulan. Pengecekan keabsahan temuan pada data dilakukan dengan menggunakan triangulasi metode. Triangulasi dilakukan terhadap metode pengumpulan data dengan cara mengecek kesamaan data dari penggunaan metode pengumpulan data yang berbeda. Metode pengumpulan data tersebut adalah meode observasi, wawancara, dan catatan lapangan.

\section{Hasil dan Pembahasan}

Penelitian ini dilaksanakan pada sejumlah 33 siswa kelas IV SD pada tema Selalu Berhemat Energi dengan sub tema Sumber Energi yang terdiri dari 6 pembelajaran. Setiap pembelajaran dilaksanakan dengan alokasi waktu $7 \times 35$ menit. Fogarty (1991: 54), menyatakan bahwa model tematik (webbed) sering dicapai melalui penggunaan tema yang cukup umum dan kaya. Tema tersebut sangat konseptual sehingga banyak kemungkinan berbagai disiplin ilmu, mata pelajaran, dan keragaman dapat melekat dalam satu tema tersebut. Mata pelajaran yang diintegrasikan pada sub tema Sumber Energi meliputi IPA, PPKn, SBdP, Bahasa Indonesia, IPS, matematika, dan PJOK.

Berdasarkan hasil wawancara pada tanggal 05 Agustus 2019 terhadap guru kelas IV SDN 3 Sarimulyo, kegiatan pembelajaran tematik yang dilaksanakan dikolaborasikan dengan berbagai model pembelajaran, salah satunya adalah model inkuiri terbimbing. Model inkuiri terbimbing cenderung lebih sering digunakan, karena langkah penerapannya ringan, mudah diikuti oleh siswa, dan guru juga bisa memberikan masukan serta menuntun siswa dalam kegiatan pembelajaran. Selain itu, guru juga menggunakan berbagai media pembelajaran yang relevan dengan tema yang dipelajari oleh siswa. Jika memungkinkan, biasanya guru membawa siswa untuk terjun langsung melakukan pengamatan dan percobaan, seperti yang terjadi pada sub tema sumber energi.

\section{Pelaksanaan Pembelajaran Tematik dengan Model Inkuiri Terbimbing}

Pada sub tema makananku sehat dan bergizi pembelajaran tematik dengan model inkuiri melalui tahapan open, immerse, eksplore, identify, gather, create, share, dan evaluate. Pada tahap open, guru mengemukakan problema terkait 
dengan tema sumber energi yang akan dicari jawabannya melalui kegiatan penemuan, sedangkan kegiatan siswa memfokuskan perhatian terhapap apa yang dijelaskan guru. Pada tahap immerse, guru mengarahkan siswa untuk membangun latar belakang tentang masalah yang akan dicari jawabannya melalui cerita, sedangkan siswa mengamati cerita membangkitkan pengalaman untuk membangun latar belakang bersama-sama. Pada tahap exlplore, guru membmbing siswa melakukan penemuan melalui kegiatan penyelidikan atau percobaan, sedangkan siswa mencari dan mengamati berbagai sumber untuk membangun ide dalam membentuk penyelidikan. Pada tahap identify, guru membantu siswa menggali ide-ide kreatif, sedangkan siswa mengemukakan pertanyaan dari ide-ide menarik yang mengarah pada pemecahan masalah. Pada tahap gather, kegiatan guru membantu siswa dengan informasi atau sumber data yang dibutuhkan, jika diperlukan, sedangkan siswa mengumpulkan informasi penting, baik melalui penyelidikan maupun percobaan. Pada tahap create, guru membantu siswa melakukan analisis hasil temuan, sedangkan siswa menganalisis, menyimpulkan, dan membuat presentasi. Pada tahap share, guru memberi kesempatan siswa melaporkan hasil temuan, sedangkan siswa mengomunikasikan hasil penemuan. Pada tahap evaluate, guru merangsang terjadinya interaksi antar siswa untuk saling memberikan masukan dan komentar terkait laporan yang disampaikan, sedangkan siswa saling mengkritisi dan melakukan refleksi diri.

Pelaksanaan pembelajaran tematik dengan model inkuiri terbimbing pada sub tema makananku sehat dan bergizi dapat dilihat dari hasil keterlaksanaan pembelajaran. Pengumpulan data pelaksanaan pembelajaran dilakukan dengan menggunakan lembar observasi keterlaksanaan pembelajaran, dengan sistem penilaian menggunakan skala likert. Observasi keterlaksanaan pembelajaran dilakukan pada setiap kegiatan pembelajaran, mulai pembelajaran 1 hingga pembelajaran 6. Selain itu, peneliti juga menggunakan catatan lapangan dalam bentuk jurnal harian guru untuk menuliskan aktivitas ataupun hal-hal penting yang dilakukan selama pembelajaran. Adapun data hasil pelaksanaan pembelajaran tematik dengan model inkuiri terbimbing dapat dilihat pada tabel 1.

Tabel 1. Rata-rata Keterlaksanaan Pembelajaran

\begin{tabular}{|c|c|c|}
\hline \multirow{2}{*}{ Pembelajaran ke- } & \multicolumn{2}{|c|}{ Nilai rata-rata } \\
\cline { 2 - 3 } & Guru (\%) & Siswa (\%) \\
\hline 1 & 85 & 85 \\
\hline 2 & 92,5 & 85 \\
\hline 3 & 87,5 & 85 \\
\hline 4 & 90 & 82,5 \\
\hline 5 & 87,5 & 90 \\
\hline 6 & 92,5 & 80 \\
\hline
\end{tabular}




\begin{tabular}{|c|c|c|}
\hline Rata-rata (\%) & 89,12 & 84,58 \\
\hline $\begin{array}{c}\text { Rata-rata } \\
\text { keterlaksanaan (\%) }\end{array}$ & \multicolumn{3}{|c|}{86,85} \\
\hline
\end{tabular}

Perhitungan lembar observasi keterlaksanaan pembelajaran dianalisis dengan menggunakan prosentase yang selanjutnya dikategorikan berdasarkan kriteria yang ditetapkan menurut Djali \& Muldjono (2008), yakni: sangat efektif (skor 86100), efektif (71-85), cukup efektif (56-70), tidak efektif (41-55), sangat tidak efektif (20-40). Berdasarkan tabel 1, dapat diketahui bahwa rata-rata keterlaksanaan pembelajaran tematik dengan model inkuiri terbimbing pada sub tema sumber energy adalah $86,85 \%$ yang dapat dikategorikan sangat efektif. Data tersebut menggambarkan bahwa tahapan pelaksanaan pembelajaran tematik dengan model inkuiri terbimbing dilakukan dengan sangat baik.

Berdasarkan hasil observasi dengan menggunakan lembar keterlaksanaan pembelajaran dapat diketahui bahwa guru dan siswa dapat melaksanakan tahaptahap pembelajaran tematik dengan model inkuiri terbimbing dengan sangat baik, hal tersebut tampak pada hasil rata-rata keterlaksanaan pembelajaran 1 sampai pembelajaran 6 mencapai 89,12\% dengan kategori sangat efektif. Berdasarkan hasil observasi dan catatan lapangan, guru mengawali pembelajaran sub tema sumber energi dengan membentuk kelompok kecil dengan beranggotakan 4-5 siswa. Pada kegiatan awal implementasi pembelajaran tematik dengan model inkuiri terbimbing, guru membawa siswa untuk mengamati sebuah gambar seorang ibu yang menjemur pakaian di bawah terik sinar matahari. Melalui gambar tersebut guru berusaha memancing siswa untuk berfikir tentang pemanfaatan matahari sebagai sumber kehidupan di bumi. Siswa terus berlanjut mengikuti kegiatan yang diintruksikan oleh guru dengan tertib dan lancar.

Pada pembelajaran ke-3, suasana kelas menjadi lebih ramai, hal ini karena siswa mulai membuat kincir dan melakukan percobaan dengan air mengalir. Pada kegiatan tersebut, guru lebih aktif mengawasi siswa guna mencegah agar air tidak mengotori kelas dan tidak dimanfaatkan untuk bermain. Pada akhir pembelajaran, yakni pada pembelajaran 6, guru mengadakan evaluasi dan refleksi yang bertujuan untuk mengetahui tingkat pemahaman siswa terhadap materi yang telah dipelajari dan mengetahui ketercapaian target indikator yang telah ditetapkan. Selain itu, guru juga melakukan instropeksi terhadap kinerjanya selama pembelajaran sub tema sumber energi berlangsung.

Berdasarkan hasil observasi dengan menggunakan lembar keterlaksanaan pembelajaran dapat diketahui bahwa siswa mampu mengikuti tahap-tahap pelaksanaan pembelajaran tematik dengan model inkuiri terbimbing dengan baik. 
Hal tersebut dapat dilihat pada tabel 1, hasil keterlaksanaan pembelajaran siswa adalah 84,58\% dengan kategori efektif. Pada kegiatan pembelajaran tematik dengan model inkuiri terbimbing, pembelajaran dilaksanakan secara bervariasi. pada setiap pembelajaran, siswa melakukan kegiatan kelompok dan juga kegiatan individu dalam waktu yang berbeda. Terdapat beberapa kompetensi yang mengharuskan siswa melakukan kegiatan secara individu, seperti kompetensi pada mata pelajaran PJOK dan SBdP.

Secara keseluruhan, siswa mampu mengikuti pembelajaran tematik dengan model inkuiri terbimbing dengan baik dan lancar. Pada pelaksanaannya, tidak ada siswa yang mengeluhkan kesulitan atau keberatan mengikuti serangkaian tahap pembelajaran. Siswa terlihat merasa senang dan sangat antusias dalam kegiatan percobaan dan penyelidikan yang dilakukan. Berdasarkan wawancara yang dilakukan setelah pembelajaran 6, guru menyatakan siswa lebih mudah memahami konsep materi. Pembelajaran tematik dengan model inkuiri terbimbing memudahkan siswa dalam belajar, siswa banyak melakukan percobaan dan pengamatan yang sesungguhnya, tidak hanya sekedar menerima sebuah konsep dari buku atau mendengar penjelasan guru. Joyce, Weil, \& Calhoun (2009) mengungkapkan bahwa jika siswa belajar melalui lingkungan dan hal-hal yang konkret maka siswa akan menemukan pengalaman yang bermakna dimana siswa belajar dan bagaimana siswa belajar.

Berdasarkan wawancara yang dilakukan setelah pembelajaran ke-5, siswa menuturkan bahwa dengan kegiatan yang mereka laksanakan yakni percobaan dan penyelidikan secara berkelompok membuat siswa tidak bosan dan merasa senang. Menurut siswa, hal tersebut karena kegiatan pembelajaran menjadi lebih bervariasi, tidak sekedar menyimak dan mengerjakan tugas pada LKS. Hal ini sejalan dengan pendapat yang diungkapkan oleh Eggen \& Kauchak (2012), yang menyatakan bahwa penggunaan inkuiri terbimbing dapat meningkatkan motivasi siswa dalam belajar, karena dalam penggunaan inkuiri terbimbing mengembangkan kegiatan dan pengalaman yang membangkitkan rasa ingin tahu pada diri siswa.

\section{Sikap Siswa Kelas IV SD pada Pembelajaran Tematik dengan Model Inkuiri Terbimbing}

Perilaku siswa pada saat kegiatan pembelajaran maupun di luar pembelajaran dilakukan melalui penilaian sikap. Penilaian sikap bertujuan guna membina perilaku siswa dalam rangka pembentukan karakter siswa. penilaian sikap dalam penelitian ini difokuskan terhadap sikap sosial siswa. Sikap sosial siswa dinilai dengan teknik observasi, dan catatan lapangan. Peneliti menggunakan 
lembar observasi guna mengamati sikap teliti dan bertangung jawab dari siswa selama kegiatan pembelajaran berlangsung, yakni mulai pembelajaran 1 sampai pembelajaran 6. Sedangkan catatan lapangan dilakukan dengan menggunakan lembar jurnal harian guru yang bertujuan untuk menuliskan peristiwa-peristiwa penting yang terjadi selama kegiatan pembelajaran berlangsung.

Pengolahan penilaian sikap selama pembelajaran tema selalu berhemat energi sub tema sumber energi dilakukan dengan melakukan rekapitulasi hasil penilaian selama pembelajaran 1 sampai pembelajaran 6. Melalui pembelajaran tematik dengan model inkuiri terbimbing ada dua sikap sosial yang dikembangkan pada tema selalu berhemat energi sub tema sumber energi, yaitu sikap teliti dan bertanggung jawab.

Indikator sikap teliti meliputi: (1) mengerjakan tugas dengan cermat; (2) berhati-hati dalam menyelesaikan tugas dan peralatan; (3) mampu menyelesaikan pekerjaan dengan standar mutu; dan (4) mampu menyelesaikan pekerjaan dengan standar waktu. Sedangkan Indikator sikap bertanggung jawab meliputi: (1) menyelesaikan tugas yang diberikan; (2) mengakui kesalahan; (3) melaksanakan tugas yang menjadi kewajibannya, seperti piket dan mengerjakan PR; dan (4) mengikuti intruksi dengan tertib. Selanjutnya, hasil penilaian sikap diinterpretasikan kembali dengan kategori belum terlihat (BT), mulai terlihat (MT), mulai berkembang (MB), dan membudaya (M). Adapun hasil observasi sikap sosial yang dikembangkan selama penelitian adalah sebagai berikut.

Tabel 2. Deskripsi hasil Observasi Sikap Teliti

\begin{tabular}{|c|c|c|c|c|c|c|c|c|}
\hline \multirow{2}{*}{ Pembelajaran } & \multicolumn{2}{|c|}{ BT } & \multicolumn{2}{c|}{ MT } & \multicolumn{2}{c|}{ MB } & \multicolumn{2}{c|}{ M } \\
\cline { 2 - 9 } & $\mathbf{( 1 )}$ & $\mathbf{( 2 )}$ & $\mathbf{( 1 )}$ & $\mathbf{( 2 )}$ & $\mathbf{( 1 )}$ & $\mathbf{( 2 )}$ & $\mathbf{( 1 )}$ & $\mathbf{( 2 )}$ \\
\hline 1 & 5 & 7 & 15 & 12 & 13 & 8 & - & 6 \\
\hline 2 & 4 & 4 & 7 & 10 & 12 & 13 & 10 & 6 \\
\hline 3 & 2 & 3 & 8 & 10 & 11 & 11 & 12 & 9 \\
\hline 4 & 2 & 1 & 3 & 3 & 13 & 16 & 15 & 13 \\
\hline 5 & - & 1 & 8 & 1 & 10 & 14 & 15 & 17 \\
\hline 6 & - & - & 1 & 1 & 14 & 12 & 18 & 20 \\
\hline
\end{tabular}

Keterangan: (1) sikap teliti; dan (2) sikap bertanggung jawab

Berdasarkan tabel 2, dapat diketahui bahwa sikap teliti siswa pada pembelajaran 1 terdapat 5 siswa dengan kategori belum terlihat, 15 siswa mulai terlihat, dan 13 siswa mulai berkembang. Sedangkan sikap bertanggung jawab, terdapat 7 siswa dengan kategori belum terlihat, 12 siswa mulai terlihat, dan 8 siswa mulai berkembang. Dari hasil catatan lapangan, pada pembelajaran 1 siswa melakukan kegiatan peneitian untuk mengetahui peran matahari terhadap kehidupan tumbuhan. Pada kegiatan tersebut, siswa menyiapkan alat dan bahan 
sendiri sesuai dengan intruksi guru, namun setelah pembelajaran masih banyak siswa yang tidak mengembalikan barang pada tempat semula secara rapi. Misalnya, tanaman yang selesai digunakan pengamatan tidak ditata seperti sedia kala, siswa hanya mengembalikan tanaman di rak tanaman yang terdapat di depan kelas tanpa merapikan kembali seperti semula. Hal tersebut menunjukkan bahwa siswa masih banyak yang belum terlihat memiliki siap teliti dan bertanggung jawab.

Perkembangan sikap teliti siswa pada pembelajaran 2, terdapat 4 siswa dengan kategori belum terlihat, 7 siswa mulai terlihat, dan 12 siswa mulai berkembang, dan 10 siswa telah membudaya. Sedangkan untuk sikap bertanggung jawab, terdapat 4 siswa dengan kategori belum terlihat, 10 siswa mulai terlihat, 13 siswa mulai berkembang, dan 6 siswa telah membudaya. Pada salah satu kegiatan, yakni mengidentifikasi hak dan kewajiban, siswa diminta untuk mengamati gambar selama 15 menit dan mengklasifikasikan gambar tersebut dengan anggota kelompoknya. Saat waktu selesai, masih ada 4 kelompok yang belum menyelesaikan tugasnya tepat waktu. Hal tersebut menandakan bahwa, sikap teliti dan bertanggung jawab masih perlu terus dikembangkan pada diri siswa.

Pada pembelajaran 3, terdapat 2 siswa dengan kategori belum terlihat, 8 siswa mulai terlihat, dan 11 siswa mulai berkembang, dan 12 siswa telah membudaya. Sedangkan pada sikap bertanggung jawab, terdapat 3 siswa dengan kategori belum terlihat, 10 siswa mulai terlihat, dan 11 siswa mulai berkembang, dan 9 siswa telah membudaya.

Pada pembelajaran 4, terdapat 2 siswa dengan kategori belum terlihat, 3 siswa mulai terlihat, dan 13 siswa mulai berkembang, dan 15 siswa telah membudaya. Sedangkan pada sikap bertanggung jawab, terdapat 1 siswa dengan kategori belum terlihat, 3 siswa mulai terlihat, dan 16 siswa mulai berkembang, dan 13 siswa telah membudaya. Pada pembelajaran 4, terlihat bahwa mulai banyak siswa yang sikap sosialnya sudah mulai berkembang dan membudaya. Hal tersebut juga dapat diketahui dari hasil catatan lapangan, siswa sudah mulai melakukan kegiatan secara berkelompok dengan tertib, menyelesaikan pekerjaan sesuai dengan standar waktu dan standar mutu. Namun, masih ada pula siswa yang masih belum terlihat bertanggung jawab, misalnya dengan tidak membantu kelompoknya dalam menyelesaikan tugas dan intruksi dari guru. Ada pula siswa yang belum terlihat cermat dalam menyelesaikan tugas.

Pada pembelajaran 5, tidak terdapat siswa dengan kategori belum terlihat, 8 siswa mulai terlihat, dan 10 siswa mulai berkembang, dan 15 siswa telah membudaya. Sedangkan untuk sikap bertanggung jawab, terdapat 1 siswa dengan kategori belum terlihat, 1 siswa mulai terlihat, dan 14 siswa mulai berkembang, 
dan 17 siswa telah membudaya. Dari hasil tersebut dapat diketahu bahwa sebagian besar siswa sudah mulai membudayakan sikap teliti dan bertanggung jawab. Siswa sudah mulai membangun kesadaran untuk menjalankan sikap teliti dan bertanggung jawab tanpa intruksi dari guru, misalnya ketika melakukan pengamatan dan diskusi tentang pemanfaatan sumber daya alam untuk kehidupan masyarakat, siswa dapat menjawab persoalan sesuai dengan standar waktu yang ditetapkan, siswa juga memiliki kesadaran untuk merapikan kembali meja kerjanya kegiatan pembelajaran selesai.

Pada pembelajaran 6, tidak terdapat siswa dengan kategori belum terlihat, 1 siswa mulai terlihat, dan 14 siswa mulai berkembang, dan 18 siswa telah membudaya. Sedangkan pada sikap bertanggung jawab, tidak terdapat siswa dengan kategori belum terlihat, 1 siswa mulai terlihat, dan 12 siswa mulai berkembang, dan 20 siswa telah membudaya. Dari hasil tersebut, jumlah siswa yang telah membudayakan sikap teliti dan bertanggung jawab lebih besar dari pembelajaran sebelumnya. Dari hasil catatan lapangan juga tampak siswa sebagian besar siswa sudah mulai terbiasa dengan tanggung jawabnya, baik ketika bekerja secara individu maupun berkelompok. Saat memecahkan permasalahan secara berkelompok, tidak ada lagi siswa yang tidak berkontribusi aktif dalam kegiatan. Namun, masih ada sebagian siswa yang mulai berkembang dan masih membutuhkan bimbingan untuk membudayakan sikap teliti dan bertanggung jawab.

Berdasarkan hasil wawancara dengan siswa setelah pembelajaran 6, siswa mengaku tidak bosan dengan pembelajaran, kegiatan pembelajaran menjadi lebih bervariasi, tidak membosankan, dan ada aktivitas yang dilakukan di luar ruangan. Melakukan aktivitas di luar kelas merupakan hal yang menyenangkan bagi siswa, menurut siswa mereka bisa lebih santai dan sambil bermain. Berdasarkan hasil wawancara degan guru, menyatakan bahwa banyak tantangan dalam pembelajaran tematik dengan model inkuiri terbmbing. Karena aktivitas siswa yang beragam, gru harus bisa menguasai kelas, mengendalikan, dan mendisiplinkan siswa. Terlebih lagi saat siswa melakukan kegiatan penyelidikan di luar kelas, guru harus ekstra teliti dan bersabar dalam membimbing dan memberikan intruksi kepada siswa. Namun, secara keseluruhan guru berpendaat bahwa pembelajaran tematik dengan model inkuiri terbimbing ini menarik dan bisa menjadi alternatif pilihan, dengan serangkaian kegiatan yang mengaktifkan siswa, sikap sosial siswa bisa lebih berkembang karena siswa banyak berinteraksi dan bekerja sama dengan teman dan lingkungan sekitarnya.

Pembelajaran dengan model inkuiri terbimbing berbasis penyelidikan atau percobaan. Model ini merupakan metode yang digunakan ilmuwan dalam 
menemukan ilmu pengetahuan, karena melalui metode ini dapat merangsang daya temu dan kemampuan berpikir kritis siswa dengan memecahkan masalah, menyusun kesimpulan atau menemukan konsep dari dari fakta-fakta yang ditemukan, serta menghubungkan temuan dengan pengalaman sehari-hari. Peran guru dalam menumbuhkan dan mengembangkan sikap ilmiah menjadi salah satu hal penting dalam pembelajaran. Untuk tingkat SD, yang perlu ditekankan dalam proses pembelajaran adalah tahapan-tahapan dan kebiasaan seorang ilmuwan yang dapat dilatihkan kepada anak-anak. Menurut Suastra (dalam Sudarma, 2012), penumbuhan sikap siswa dilakukan dengan meniru cara kerja para ilmuwan (scientific) menerapkan sikap ilmiah dalam melakukan penelitiannya.

Berdasarkan hasil analisis data menunjukkan bahwa sikap siswa pada pembelajaran tematik dengan model inkuiri terbimbing mengalami perkembangan yang positif. Pada pembelajaran 1, sikap sosial siswa masih dominan mulai terlihat. Sedangkan pada pembelajaran 2, mulai berkembang sikap sosialnya. Dilanjutkan pada pembelajaran 3 dan 4, sosial siswa sebagian besar mulai berkembang dan membudaya, dan pada pembelajaran 5 dan 6 sebagian besar siswa sikap sosialnya sudah membudaya. Hal tersebut menandakan bahwa sikap sosial dapat dikembangkan pada diri siswa melalui kegiatan-kegiatan pembelajaran berbasis proses penyelidikan dan percobaan seperti inkuiri terbimbing. Sudarma (2012) menyatakan sejak dini siswa dapat diperkenalkan dengan kegiatan-kegiatan tertentu melalui metode ilmiah atau proses ilmiah dalam pembelajaran. Melalui pembelajaran dengan model inkuiri terbimbing, siswa selalu dituntun untuk melakukan proses ilmiah melalui pengalaman belajar yang nyata dalam memecahkan masalah, membuat keputusan, dan memperoleh ketarampilan.

Beberapa saran yang dapat dilakukan dalam mengembangkan sikap sosial siswa adalah dengan memperlihatkan contoh, memberi penguatan positif terhadap sikap siswa dengan ujian dan penghargaan, memberikan kesempatan untuk mengembangkan sikap siswa, dan mendiskusikan tingkah laku yang berhubungan dengan sikap (Harlen \& Elstgeest, 2012). Memperlihatkan contoh sikap sosial yang baik adalah salah satu hal penting dan positif yang dapat dilakukan guru kepada siswa, misalnya dengan menyelesaikan pekerjaan sesuai standard an telat waktu, mengakui kesalahan jika ada perilaku atau penjelasan yang tidak tepat, berperilaku tertib, dan sebagainya. Ketika siswa juga dapat melakukan hal yang sama, maka guru patut memberikan apresisi dengan memberikan kepada siswa.

\section{Simpulan}

Berdasarkan hasil dan pembahasan dapat disimpulkan bahwa: (1) guru dan siswa dapat melaksanakan tahap-tahap pembelajaran tematik dengan model 
inkuiri terbimbing dengan sangat baik, hal tersebut tampak pada hasil rata-rata keterlaksanaan pembelajaran 1 sampai pembelajaran 6 mencapai 89,12\% dengan kategori sangat efektif; dan (2) sikap siswa pada pembelajaran tematik dengan model inkuiri terbimbing mengalami perkembangan yang positif. Pada pembelajaran 1, sikap sosial siswa masih dominan mulai terlihat. Sedangkan pada pembelajaran 2, mulai berkembang sikap sosialnya. Dilanjutkan pada pembelajaran 3 dan 4, sosial siswa sebagian besar mulai berkembang dan membudaya, dan pada pembelajaran 5 dan 6 sebagian besar siswa sikap sosialnya sudah membudaya. Hal tersebut menandakan bahwa sikap sosial dapat dikembangkan pada diri siswa melalui kegiatan-kegiatan pembelajaran berbasis proses penyelidikan dan percobaan seperti inkuiri terbimbing.

Pembelajaran tematik dengan model inkuiri terbimbing dapat dijadikan sebagai salah satu alternatif dalam pembelajaran. Pada pembelajaran tematik dengan model inkuiri terbimbing, guru berperan aktif mendampingi dan membimbing kegiatan siswa agar target penemuan sebuah konsep dapat terpenuhi. Ketika merancang pembelajaran, guru juga hendaknya memperhatikan alokasi waktu, hal ini bertujuan agar kegiatan pembelajaran bisa berlangsung dengan efektif dan efisien.

\section{Daftar Rujukan}

Ammah, E. S. (2017). Sintesis Hasil Penelitian Membaca Sebagai Landas Pijak Penyusunan Pembelajaran Membaca Dalam Bingkai Kurikulum 2013. ArRisalah: Media Keislaman, Pendidikan dan Hukum Islam, 14(2), 38-48.

Ammah, E. S. (2016). Pengaruh model pembelajaran demonstrasi diskusi terhadap keterampilan menulis teks diskusi siswa kelas VIII SMPN 10 Malang. Tesis tidak diterbitkan. Malang: PPs UM.

Dimyati \& Mudjiono. (2006). Belajar dan Pembelajaran. Jakarta: PT Rineka Cipta

Dewi, Nur Laela, Ahmad Izza Muttaqin, and Al Muftiyah. 2019. "IMPLEMENTASI STRATEGI INFORMATION SEARCH DENGAN MEMAKSIMALKAN PENGGUNAAN SMARTPHONE DALAM PEMBELAJARAN PAI KELAS X MIPA 1 DI SMA NEGERI 1 GENTENG TAHUN PELAJARAN 2018/2019." Tarbiyatuna: Kajian Pendidikan Islam 3(2):171-86.

Djali \& Mudjiono. (2008). Pengukuran dalam Pendidikan. Jakarta: PT Grasindo 
Eggen, P. \& Kauchak, D. (2012). Strategi dan Model Pembelajaran. Terjemahan Satrio Wahono. 2012. Jakarta: PT Indeks

Fitriyanti. (2012). Pendekatan Inkuiri Terbimbing untuk Meningkatkan Keterampilan Belajar Peserta Didik pada Pembelajaran Tematik SDN 3 Candimulyo Tahun 2018/2019. Indonesian Journal of Education and Learning: Vol 3 Nomor 1 Oktober 2019. (25 Juni 2020)

Forgarty, R. 1991. The Mindull School: How To Integrate The Curicula. Illinois: IRI/Skylight Publishing, Inc.

Harlen, W. \& Elstgeest, J. (1992). Unesco Sourcebook For Science In The Primary School. (Online),(http://vidyaonline.org/dl/unescoprimary.pdf). (28 Oktober 2014)

Harsiati, T. (2011). Penilaian dalam Pembelajaran. Malang: UM Press

Joyce, B., Weil, M., \& Calhoun, E. (2009). Model-model Pengajaran. Terjemahan Ahmad Fawaid \& Ateila Mirza. 2009. Yogyakarta: Pustaka Pelajar

Kuhltahau, C.C, Maniotes, L.K. \& Caspari, A.K. (2012). Guided Inquiry Design: A Framework for Inquiry in Your School. California: ABC-CLIO, LCC

Lestari, S. (2015). Pengaruh Model Inkuiri Terbimbing terhadap Sikap Ilmiah, Keterampilan Proses Sains, dan Penguasaan Konsep pada Siswa Kelas IV SDN 4 Cluring Banyuwangi. Tesis tidak diterbitkan. Malang: PPs UM.

Mbulu, J. (2001). Pengajaran individual: konsep dasar, metode dan media. Malang: Yayasan Elang Mas

Miles, M.B. \& Huberman, A.M. (1992). Analisis Data Kualitatif. Terjemahan Rohidi, T.R. 2014. Jakarta: Penerbit Universitas Indonesia (UI-Press)

Moleong, L.J. (2012). Metodologi Penelitian Kualitatif. Bandung: PT Remaja Rosdakarya

Rusman. (2012). Model-Model Pembelajaran. Jakarta: PT. Raja Grafindo Persada 
Sudarsri Lestari, Erisy Syawiril Ammah, Eka Ramiati

Sudarma, I, K. 2012. Pengaruh Penerapan Strategi Pembelajaran dan Pengetahuan Awal terhadap Pemahaman Konsep Sains dan Sikap Ilmiah Siswa Kelas V di Sekolah Dasar. Diertasi tidak diterbitkan. Malang: PPs UM.

Widyastono, H. 2014. Pengembangan Kurikulum di Era Otonomi Daerah. Jakarta: Bumi Aksara

Winkel, M.S. Psikologi Pengajaran. Jakarta: PT Gramedia 